\title{
Hypertension and its correlation with renal lesions in dogs with leishmaniosis
}

\author{
Hipertensão e sua correlação com lesóes renais em cães com leishmaniose \\ Eveline Tozzi Braga ${ }^{1}$; João Henrique Artero de Carvalho Leite ${ }^{1}$; Fernando Azadinho Rosa ${ }^{1}$; Patrícia Tivelli ${ }^{1}$; \\ Amanda Mariano Araújo ${ }^{1}$; Breno Fernando Martins de Almeida ${ }^{1}$; Heitor Flávio Ferrari' ${ }^{1}$; Paulo César Ciarlini ${ }^{1}$; \\ Gisele Fabrino Machado ${ }^{1}$; Mary Marcondes ${ }^{1 *}$
}

\begin{abstract}
${ }^{1}$ Departamento de Clínica, Cirurgia e Reprodução Animal, Faculdade de Medicina Veterinária, Universidade Estadual Paulista - UNESP, Araçatuba, SP, Brasil
\end{abstract}

Received September 10, 2014

Accepted November 5, 2015

\begin{abstract}
To evaluate the prevalence of hypertension and its correlation with the severity of renal injury and proteinuria in dogs with leishmaniosis, sixty-six dogs were divided into two groups. Group 1 (G1) was composed of 54 dogs included in stage 1 of chronic kidney disease (CKD), and group 2 (G2) of twelve dogs in stages 2 and 3 of CKD. Prevalence of hypertension was $28.8 \%$, comprising $22.2 \%$ of the dogs from G1 and $58.3 \%$ from G2 ( $P=0.011)$. The mean arterial blood pressure (BP) of dogs from G1 $(135.7 \pm 20.5)$ was lower than from G2 $(170.0 \pm 26.3)(P<0.001)$. Urine proteincreatinine ratio (UP/C) revealed values above 0.5 in $75.7 \%$ of the dogs, with $34 \%$ presenting hypertension. All dogs with hypertension had histopathological and laboratory evidence of glomerular disease. Although there was no statistically significant correlation between elevated BP and the severity of glomerular lesions $(P=0.408)$, there was a statistically significant correlation between elevated BP and increased UP/C in the studied population $(P=0.002)$. Thus, dogs with leishmaniosis and renal disease must be screened for the presence of hypertension so that treatment may be instituted as early as possible, in countries where treatment is allowed, to prevent the progression of renal damage.
\end{abstract}

Keywords: Histopathology, kidney, Leishmania infantum chagasi, systolic blood pressure.

\section{Resumo}

Para avaliar a prevalência de hipertensão arterial e sua correlação com a severidade da lesão renal e proteinúria em cães com leishmaniose, 66 cães foram divididos em dois grupos. O grupo 1 (G1), composto por 54 cães em estágio 1 de doença renal crônica (DRC), e o grupo 2 (G2) por 12 cães em estágios 2 e 3 de DRC. A prevalência de hipertensão foi de $28,8 \%$, compreendendo $22,2 \%$ dos cães de $\mathrm{G} 1$ e $58,3 \%$ dos cães de $\mathrm{G} 2$ ( $\mathrm{p}=0,011$ ). A pressão arterial média $(\mathrm{PA})$ de G1 $(135,7 \pm 20,5)$ foi inferior a de G2 $(170,0 \pm 26,3)(\mathrm{P}<0,001)$. A relação proteína creatinina urinária $(\mathrm{P} / \mathrm{C} \mathrm{U})$ foi maior que $0,5 \mathrm{em} 75,7 \%$ dos cães, dos quais $34 \%$ possuíam hipertensão. Todos os cães com hipertensão apresentavam doença glomerular. Embora não tenha sido observada correlação estatisticamente significativa entre elevação da PA e severidade das lesóes glomerulares ( $\mathrm{P}=0,408)$, houve uma correlação significativa entre PA elevada e aumento da UP/C $(\mathrm{P}=0,002)$. Portanto, cães com leishmaniose e doença renal devem ser pesquisados quanto à presença de hipertensão, para que o tratamento possa ser instituído o mais precocemente possível em países onde ele é permitido, para evitar a progressão da lesão renal.

Palavras-chave: Histopatologia, rim, Leishmania infantum chagasi, pressão arterial sistólica.

\section{Introduction}

Canine leishmaniosis (CanL) is an endemic disease in Brazil, caused by Leishmania infantum chagasi (SHAW, 2006). Infected dogs can be asymptomatic or present variable clinical signs. The most commonly observed are weight loss, lymphadenomegaly,

*Corresponding author: Mary Marcondes, Departamento de Clínica, Cirurgia e Reproduçáo Animal, Faculdade de Medicina Veterinária, Universidade Estadual Paulista "Júlio de Mesquita Filho", Rua Clóvis Pestana, 793, Jardim Dona Amélia, CEP 16050-680, Araçatuba, SP, Brasil, e-mail: marcondes@fmva.unesp.br splenomegaly, cutaneous and ocular lesions and impaired renal function (SOLANO-GALLEGO et al., 2011). Chronic kidney disease $(\mathrm{CKD})$ is a severe result of disease progression and the main cause of death or an indication for euthanasia in infected dogs (PLANELLAS et al., 2009; SOLANO-GALLEGO et al., 2011; BANETH \& SOLANO-GALLEGO, 2012; ROURA et al., 2013). While Cortadellas et al (2006) used the assessment of serum creatinine and $\mathrm{UP} / \mathrm{C}$ and observed prevalence rates of $\mathrm{CKD}$ on the 
order of $49.5 \%$, others based their assessments on postmortem histopathological studies and showed renal changes in nearly $100 \%$ of the dogs (NIETO et al., 1992; COSTA et al., 2003).

Among dogs with leishmaniosis, the ones with CKD usually have a lower recovery rate compared to those without renal impairment or to those with only a moderate degree of proteinuria (SOLANO-GALLEGO et al., 2011). Quantification of proteinuria is essential in the assessment of CKD because it allows evaluation of the severity of renal lesions and disease progression (JACOB et al., 2005). Renal involvement in CanL is mainly attributed to immune complex deposition and subsequent glomerular injury (POLI et al., 1991; SOLANO-GALLEGO et al., 2007). Most of the dogs present glomerular and tubulointerstitial lesions (COSTA et al, 2003). Among the glomerular alterations, the most commonly reported are membranoproliferative glomerulonephritis, mesangioproliferative glomerulonephritis and glomerulosclerosis (POLI et al., 1991; NIETO et al., 1992, COSTA et al., 2003).

Renal lesions lead not only to complications arising from the accumulation of uremic toxins and electrolyte imbalances but also from systemic arterial hypertension, worsening clinical status and compromising other organs such as the heart (SCHIFFRIN et al., 2007). Systemic hypertension, by the other hand, perpetuates vascular damage and increases peripheral and renal vascular resistance, worsening renal injuries and leading to renal failure and death (JACOB et al., 2005; AMANN et al., 2006; SCHIFFRIN et al., 2007). There are discrepancies in the literature regarding the percentage of dogs with kidney disease that develop systemic hypertension (MICHELL et al., 1997; JACOB et al., 2003; POLZIN, 2012). Such divergences may be due to different stages as well as to the nature of renal disease, because glomerulopathies are more likely to cause hypertension than tubulointerstitial diseases (CORTADELLAS et al., 2006; BACIC et al., 2010). There is only one previous study that evaluated the prevalence of hypertension in dogs with leishmaniosis, which revealed that $61.5 \%$ of the dogs with glomerular disease were hypertensive. In this study the authors did not perform histopathological evaluation of the kidneys, and glomerular disease was diagnosed by the presence of proteinuria (CORTADELLAS et al., 2006).

Thus, the aim of the present study was to evaluate the prevalence of hypertension and its correlation with the severity of renal injury and proteinuria in dogs with leishmaniosis.

\section{Materials and Methods}

\section{Dogs}

The present study was approved by the Committee for Ethics in Animal Research, of São Paulo State University (protocol 2010000156). From January to December 2012, dogs naturally affected by leishmaniosis were selected from the Veterinary Teaching Hospital of São Paulo State University in Araçatuba, Northwestern São Paulo State, Brazil, an endemic area for the disease. Diagnosis of CanL was based on enzyme-linked immunosorbent assay (ELISA) and confirmed by cytologic examination of lymph node and bone marrow samples. Blood and urine samples were obtained for the determination of serum creatinine, urinalysis and urine protein-creatinine ratio (UP/C). Systolic blood pressure (SBP) was determined in all dogs, and after that the dogs were euthanased in compliance with a federal law. The kidneys were removed, and renal tissue was evaluated by histopathology. Only dogs with renal histopathological abnormalities were included in the study. Dogs with diseases that could be associated with hypertension or glomerulopathies, such as heart disease, diabetes mellitus, hypothyroidism and hyperadrenocorticism, and dogs with urinary tract infections were excluded from the study. All dogs underwent serology for detection of Dirofilaria immitis antigens and Ehrlichia canis, Anaplasma phagocytophilum and Borrelia burgdorferi antibodies by the commercial SNAP 4DX test (IDEXX Laboratories Inc.), and those who had positive results for any of the four infectious agents were also excluded. Thus, sixty-six dogs, 32 females and 34 males, with ages ranging from six months to five years, were included.

In order to correlate the severity of renal injury with the presence of hypertension, dogs were divided into groups according to the International Renal Interest Society (IRIS) staging system for chronic kidney disease (CKD) (IRIS, 2013). The first group (G1) was composed of 54 dogs included in stage 1 of CKD, i.e., with loss of the ability to concentrate urine, persistent proteinuria of renal origin, renal histopathological abnormalities and serum creatinine $<1.4 \mathrm{mg} / \mathrm{dL}$. The second group (G2) consisted of 12 dogs, three classified in stage 2 (serum creatinine between 1.4 and $2.0 \mathrm{mg} / \mathrm{dL}$, with no clinical signs or mild signs of kidney disease), and nine dogs included in stage 3 (serum creatinine between 2.1 and $5.0 \mathrm{mg} / \mathrm{dL}$, with systemic signs of CKD).

\section{Determination of serum creatinine and $U P / C$}

Urine protein was determined by a colorimetric method with a pyrogallol-molybdate complex (Microprote Pyrogallol 50, Doles Reagentes), and urine creatinine was determined using the Jaffe method (Kit Creatinina, Biosystem), using a Chemistry Analyzer (BS-200, Mindray Bio-Medical Eletronics Co.). Reference values were considered according to the International Renal Interesty Society (IRIS).

\section{Systolic blood pressure}

Before systolic blood pressure (SBP) evaluation, dogs were housed in kennels for a period of $72 \mathrm{~h}$ where they received food and water ad libitum. During the first $24 \mathrm{~h}$, the dogs were allowed to wander around to reduce stress from being in an unfamiliar environment. On the second day SBP was determined using an ultrasonic Doppler DV-10 (Microem). For SBP measurement, the dogs were restrained in lateral recumbency in a quiet room away from other animals. The cuffs used corresponded to approximately $40 \%$ of the circumference of the limb at the site of measurement. The measurements were performed three times daily (at 8:00 a.m., 
1:00 p.m., and 6:00 p.m.) for two consecutive days. Each time the SBP values were collected, six individual measurements were performed at $10 \mathrm{~min}$ intervals. The measurements were always collected on the right forelimb at the level of the carpus. The first value was discarded, and the mean of the remaining five values was determined. Dogs were considered hypertensive when mean SBP $\geq 160 \mathrm{mmHg}$ (BROWN et al., 2007). None of the dogs in the present study had undergone any treatment with drugs that interfere with BP.

\section{Histopathology}

After the kidneys were removed, the renal tissue was fixed in buffered formalin. Kidney samples were next embedded in paraffin and then $5 \mu \mathrm{m}$-thick sections were deparaffinized in xylene and dehydrated in increasing concentrations of alcohol. Sections were stained with hematoxylin and eosin (HE), periodic acid-Schiff (PAS reaction) and Masson's trichrome stains. The sections were analyzed by light microscopy, and the renal changes were classified according to the criteria of the World Health Organization for classification of the morphologic pattern of glomerulonephritis (CHURG et al., 1995).

\section{Immunohistochemistry (IHC) for Leishmania spp.}

Deparaffinized slides were hydrated and incubated in $3 \%$ hydrogen peroxide $(10 \mathrm{v} / \mathrm{v})$ to block endogenous peroxidase activity, followed by incubation with $6 \%$ nonfat dry milk (Molico, Nestlé) diluted in 0.01 M PBS, pH 6.0, to block nonspecific immunoglobulin absorption to tissues. Antibodies against Leishmania spp. (produced in mice by the Laboratory of Pathology of Infectious Diseases, Medical School, São Paulo University) diluted 1:100 were used as the primary antibody. Slides were incubated for $18 \mathrm{~h}$ at $4{ }^{\circ} \mathrm{C}$ in a humid chamber. After washing in PBS, the slides were incubated with biotinylated secondary antibody (LSAB kit K0690, Dako), washed in PBS, and then incubated with the streptavidin-peroxidase complex for $45 \mathrm{~min}$ at $37^{\circ} \mathrm{C}$. The reaction was developed with a diaminobenzidine (Liquid DAB + Substrate Chromogen System - K3468, Dako) solution and a hydrogen peroxide $10 \mathrm{vv}$ solution. Finally, slides were dehydrated, cleared, counter-stained with Harris Hematoxylin and mounted with coverslips.

\section{Statistical analysis}

Comparisons between the groups were performed using the $t$ test, the nonparametric Mann-Whitney test and the Fisher exact test. Correlations between BP levels, histopathological changes and UP/C were evaluated by the Spearman test. Statistical analysis was performed by a commercially available software program (SAS INSTITUTE INC, 2008). For all statistical analyses $P<0.05$ was used to determine statistical significance.

\section{Results}

All dogs in this study presented clinical signs of leishmaniosis. Among the evaluated dogs, 50/66 (75.7\%) had laboratory abnormalities suggestive of renal injury, such as elevated serum creatinine, UP/C> 0.5 , loss of ability to concentrate urine and urinary casts. Moreover, all dogs had renal histopathological alterations. The prevalence of hypertension in the studied population was $19 / 66(28.8 \%)$, comprising $12 / 54$ (22.2\%) of the dogs from G1 and 7/12 (58.3\%) of the dogs from G2 ( $P=0.011$, Fisher exact test). In this group, all dogs in stage II and 4/9 (44.4\%) of the dogs in stage III of CKD were hypertensive. The mean SBP of dogs from G1 $(135.7 \pm 20.5)$ was lower than from G2 $(170.0 \pm 26.3)(P<0.001$, t test $)$. The assessment of glomerular function by $\mathrm{UP} / \mathrm{C}$ revealed values above 0.5 in $50 / 66(75.7 \%)$ of the dogs, with $17 / 50(34 \%)$ presenting with hypertension. Thirty-six (54.5\%) dogs had UP/C > 1.0, with 16/36 (44.4\%) presenting hypertension. There was a statistically significant correlation $(\mathrm{r}=0.3732)$ between elevated SBP and increased UP/C in the studied population ( $P=0.002$, Spearman test).

There was no statistically significant difference in the occurrence of glomerular $(P=0.577$, Fisher exact test $)$ and interstitial ( $P=0.486$, Fisher exact test) lesions between the two groups. Interstitial nephritis (Figure 1a) was observed in 48/66 $(72,7 \%)$ of the dogs, corresponding to $38 / 54$ (70.4\%) of the dogs from G1 and 10/12 (83.3\%) from G2. Glomerular changes were observed in all dogs. Membranoproliferative glomerulonephritis (Figure 1b) was present in 39/66 (59\%) of the dogs, corresponding to $30 / 54(45.5 \%)$ of $\mathrm{G} 1$ and $9 / 12(75 \%)$ of $\mathrm{G} 2(P=0.299$, Mann-Whitney test). Glomerular fibrosis was observed in 30/66 (45.4\%) of the dogs, representing 21/54 (38.9\%) of G1 and $9 / 12(75 \%)$ of G2, all of those 9 included in stage 3 of CKD ( $P=0.045$, Mann-Whitney test). Membranous glomerulonephritis (Figure 1c) was present in 22/66 (33.3\%) of the dogs; $19 / 54$ (35.1\%) of G1 and 3/12 (25\%) of G2 ( $P=0.739$, Mann-Whitney test). Mesangioproliferative glomerulonephritis was found in 3/66 (4.5\%) of the dogs and focal segmental glomerulonephritis in only one $(1.5 \%)$ evaluated dog. The most frequent histopathological changes observed in renal tissue from dogs in both groups, as well as their severities, are presented in Table 1. Immunohistochemistry revealed Leishmania antigens in renal tissue (Figure 1d) from 22/66 (33.3\%) of the dogs.

All dogs with hypertension had histopathological changes and laboratory evidence of glomerular disease. Membranoproliferative glomerulonephritis associated with glomerular fibrosis was observed in $7 / 19(36.8 \%)$ dogs; $5 / 19$ (26.3\%) had membranoproliferative glomerulonephritis associated with interstitial nephritis; 2/19 (10.5\%) had mild membranoproliferative glomerulonephritis; 2/19 (10.5\%) had mild membranous glomerulonephritis; 2/19 (10.5\%) had mild proliferative glomerulonephritis associated with glomerular fibrosis and 1/19 (5.3\%) had severe membranous glomerulonephritis. There was no statistically significant correlation $(\mathrm{r}=0.10198)$ between elevated SBP and the severity of glomerular lesions ( $P=0.408$, Spearman test). 


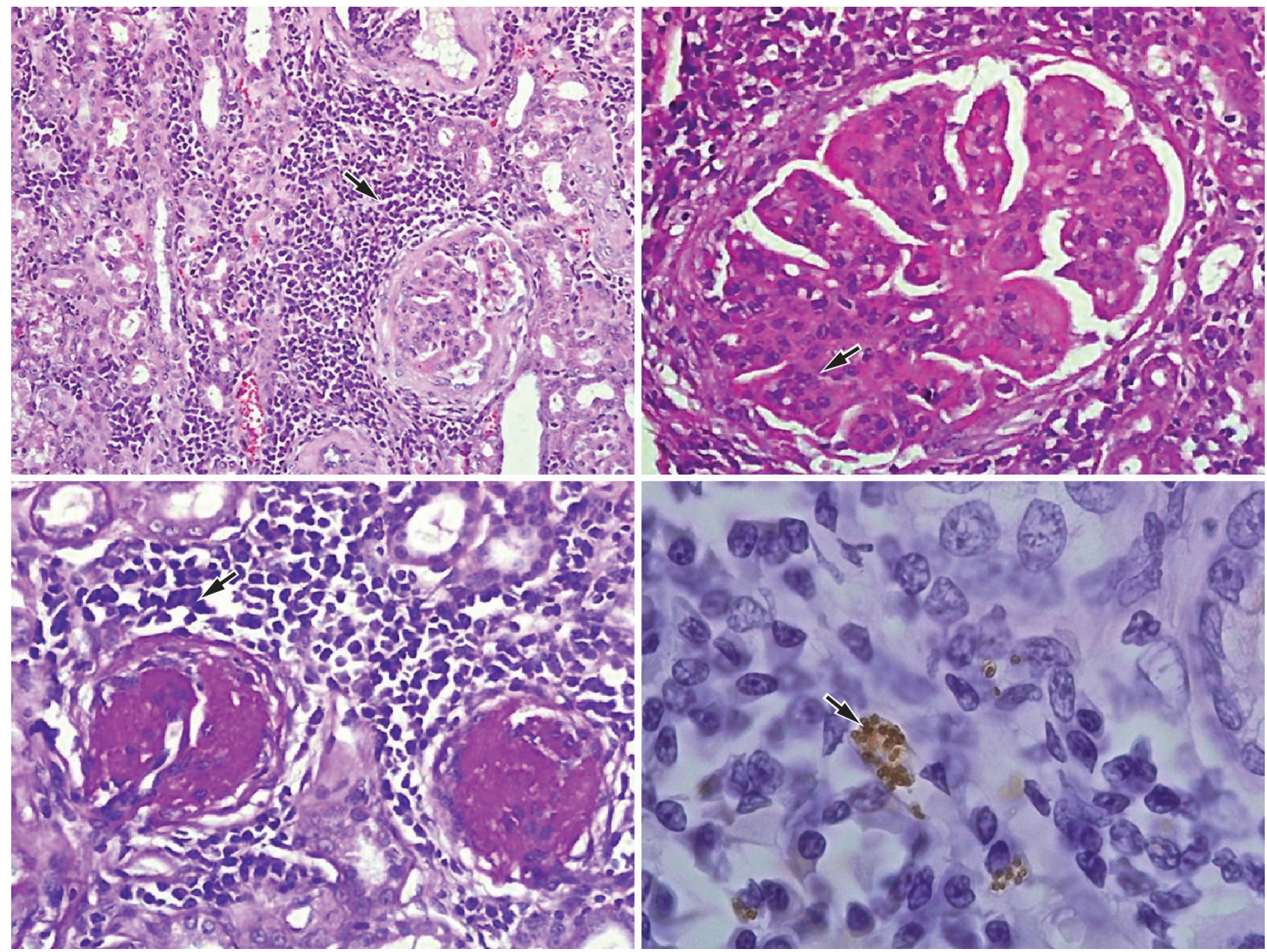

Figure 1. Photomicrograph of renal tissue from dogs naturally affected by Canine Leishmaniosis. (a) Intersticial nephritis with inflammatory infiltrate (Hematoxylin and eosin; Bar 200 $\mu \mathrm{m}$ ); (b) Membranoproliferative glomerulonephritis with mesangial cell proliferation (arrow), and thickening of Bowman's capsule $\left(^{*}\right)$ (Hematoxylin and eosin; Bar 50 $\mu \mathrm{m}$ ); (c) Membranous glomerulonephritis with tickening of Bowman's capsule $\left(^{*}\right)$ and periglomerular inflammatory infiltrate (arrow) (Periodic acid-shiff; Bar 50 $\mu \mathrm{m}$ ); (d) Immunohistochemical staining of renal tissue from dogs naturally affected by visceral leishmaniasis. Leishmania amastigotes (Streptavidin-peroxidase complex, Bar 20 $\mu \mathrm{m}$ ).

Table 1. Most frequent histopathological changes, distributed according to the intensity of the lesions, observed in renal tissue from dogs naturally affected by leishmaniosis in stage 1 (G1) and in stages 2 and 3 of chroni kidney disease (G2).

\begin{tabular}{|c|c|c|c|c|c|}
\hline \multirow{2}{*}{ Variable } & \multirow{2}{*}{ Score } & \multicolumn{2}{|c|}{ G1 $(n=54)$} & \multicolumn{2}{|c|}{ G2 $(n=12)$} \\
\hline & & $n$ & $\%$ & $n$ & $\%$ \\
\hline \multirow{4}{*}{$\begin{array}{l}\text { Membranoproliferative } \\
\text { glomerulonephritis }\end{array}$} & Absent & 23 & 42.6 & 3 & 25.0 \\
\hline & 1 & 8 & 14.3 & 1 & 8.3 \\
\hline & 2 & 17 & 30.4 & 4 & 33.3 \\
\hline & 3 & 6 & 10.7 & 4 & 33.3 \\
\hline \multirow[t]{4}{*}{ Glomerular fibrosis } & Absent & 36 & 66.6 & 4 & 33.3 \\
\hline & 1 & 10 & 17.9 & 2 & 16.7 \\
\hline & 2 & 7 & 12.5 & 4 & 33.3 \\
\hline & 3 & 1 & 1.8 & 3 & 25.0 \\
\hline \multirow[t]{4}{*}{ Membranous glomerulonephritis } & Absent & 36 & 66.6 & 9 & 75.0 \\
\hline & 1 & 10 & 17.9 & - & - \\
\hline & 2 & 7 & 12.5 & - & - \\
\hline & 3 & 1 & 1.8 & 3 & 25.0 \\
\hline \multirow[t]{4}{*}{ Interstitial nephritis Intersticial } & Absent & 16 & 29.6 & 2 & 16.7 \\
\hline & 1 & 19 & 33.9 & - & - \\
\hline & 2 & 17 & 30.4 & 6 & 50 \\
\hline & 3 & 2 & 3.6 & 4 & 33.3 \\
\hline
\end{tabular}




\section{Discussion}

In the present study from the 66 evaluated dogs, 50 (75.7\%) presented laboratory abnormalities suggestive of renal injury. Proteinuria (UP/C > 0.5) was observed in $75.7 \%$ of the studied population, which was less than that observed by Nieto et al. (1992), who detected proteinuria by dipstick in $10 / 10(100 \%)$ of the dogs with leishmaniosis. In this study, $54.5 \%$ of the dogs had UP/C > 1.0, similar to the $54.6 \%$ observed by Costa et al. (2003) and the $41.5 \%$ observed by Cortadellas et al. (2006). Although moderate proteinuria can occur in both glomerular and tubular diseases, it is usually considered characteristic of glomerular lesions, leading to a greater loss of protein when compared to tubulointerstitial diseases (JACOB et al., 2005).

Of the evaluated dogs, $28.8 \%$ had hypertension, values below those reported in a previous study where the prevalence of hypertension was $61.5 \%$ in dogs with leishmaniosis and glomerular disease (CORTADELLAS et al., 2006). This discrepancy may be partly because the authors measured $\mathrm{BP}$ in a single period over five to $10 \mathrm{~min}$, while in our study SBP was measured three times daily for two consecutive days. This procedure minimizes the chance of errors in the evaluated SBP due to so-called 'white-coat hypertension', an anxiety-induced hypertension triggered by stress associated with the measurement process that can result in a false diagnosis of hypertension (BROWN et al., 2007).

Despite identifying a prevalence of hypertension in dogs with more advanced stages of kidney disease $(P=0.011)$ and confirming the findings of Wehner et al. (2008), it was not possible to correlate SBP values with the intensity of histopathological lesions. There was an association between elevated SBP and increased UP/C $(P=0.002$, Spearman test), confirming the results of previous studies (FINCO, 2004; JACOB et al., 2005). Twenty-two percent of the dogs from group 1 were hypertensive, confirming the observations of Cortadellas et al. (2006), which stated that systemic hypertension can occur even in early stages of CKD. Both proteinuria and systemic hypertension are consequences of kidney disease, but they can also lead to a greater loss of renal function. Hypertension caused by CKD can lead to deterioration in renal function not only because it causes abnormalities in glomerular morphology and function, but also because it can result in a higher intraglomerular capillary pressure (FINCO, 2004). The association between chronic renal disease and systemic hypertension has been described in several species, and there is an association between high SBP and mortality in renal disease (FINCO, 2004).

Histologic evaluation of the kidneys in dogs with leishmaniosis identified several patterns of glomerular lesions such as membranoproliferative glomerulonephritis, membranous glomerulonephritis, mesangioproliferative glomerulonephritis, focal segmental glomerulonephritis and glomerular fibrosis. Membranoproliferative glomerulonephritis was the most frequently observed and was present in $59 \%$ of the dogs, a higher value than the $30 \%$ observed by Costa et al. (2003) and $18 \%$ observed by Rigo et al. (2013). Glomerular fibrosis was identified in $45.5 \%$ of the dogs and also described by other authors (ZATELLI et al., 2003). Fibrosis is most likely related to a more chronic stage of CKD (NEWMAN et al., 2009), which explains its occurrence mainly in dogs with uremic syndrome
( $P=0,045$, Mann-Whitney test). Membranous glomerulonephritis was present in $34.4 \%$ of the dogs and was also described by Zatelli et al. (2003) and Rigo et al. (2013), but it was not identified in the studies of Costa et al. (2003). It occurs by the deposition of immune complexes on the subepithelial surface of the glomerular basement membrane (SERAKIDES, 2010). Although a previous study identified mesangioproliferative glomerulonephritis and focal segmental glomerulonephritis in $21.9 \%$ and $19.5 \%$ of the dogs with leishmaniosis, respectively, (ZATELLI et al., 2003), these changes were found in only $4.5 \%$ and $1.5 \%$ of the dogs in this study, respectively.

Interstitial nephritis, characterized by the presence of lymphocytic infiltration, is a common finding in nephropathy due to dogs with leishmaniosis (TAFURI et al., 1989). According to Costa et al. (2000), it may be due to the presence of parasite antigens found in the inflammatory infiltrate. The occurrence of interstitial nephritis in $72.7 \%$ of the dogs in this study is similar to the results of a previous study that identified the same alteration in $78 \%$ of the dogs (COSTA et al., 2003). Because dogs from G2 showed more severe CKD (IRIS stages 2 and 3), we expected that the histopathological lesions in these dogs would be more severe, which was observed with glomerular fibrosis $(P=0.045)$.

The present study identified parasites in renal tissue from $34.4 \%$ of the dogs, lower values than those reported in previous studies that identified the parasite in $90.9 \%$ to $98 \%$ of the evaluated dogs, suggesting the involvement of the parasite in the development of renal disease (COSTA et al., 2003, 2010). There are still doubts regarding the direct participation of the parasite in the pathogenesis of renal disease in dogs with leishmaniosis because other authors, even with the use of immunohistochemistry, identified the parasite in the kidney of only $15 \%$ of the dogs (FERRARI et al., 2010).

All dogs with hypertension in our study presented with glomerular disease. Almost 74\% (14/19) of them had only glomerular alterations, while $26.3 \%$ had interstitial and glomerular lesions, confirming the report of Cortadellas et al. (2006) who stated that hypertension occurs mainly secondary to glomerulopathy.

\section{Conclusions}

Treatment of dogs with leishmaniosis is a challenge for veterinarians as the course and outcome of the disease is unpredictable. The identification of the primary cause of renal dysfunction and of the secondary factors that may contribute to the progression of the disease, such as hypertension and proteinuria, may help to establish an appropriate treatment that can reduce the progression of renal disease to the end-stage of renal failure. The results of our study indicate that despite the low prevalence of hypertension in dogs with leishmaniosis, hypertension was present in almost $29 \%$ of the affected dogs and was associated both with more advanced stages of CKD and with an increase in proteinuria. Thus, dogs with leishmaniosis and renal disease must be screened for the presence of hypertension so that treatment may be instituted as early as possible to prevent the progression of renal damage in countries where treatment is allowed. 


\section{References}

Amann K, Wanner C, Ritz E. Cross-talk between the kidney and the cardiovascular system. JAm Soc Nephrol 2006; 17(8): 2112-2119. http:// dx.doi.org/10.1681/ASN.2006030204. PMid:16825329

Bacic A, Kogika MM, Barbaro KC, Iuamoto CS, Simóes DMN, Santoro ML. Evaluation of albuminuria and its relationship with blood pressure in dogs with chronic kidney disease. Vet Clin Pathol 2010; 39(2): 203-209. http://dx.doi.org/10.1111/j.1939-165X.2009.00207.x. PMid:20059754

Baneth G, Solano-Gallego L. Canine Leishmaniasis. In: Greene CE. Infectious diseases of the dog and cat. 4th ed. Philadelphia: Saunders; 2012. p. 735-748.

Brown S, Atkins C, Bagley R, Carr A, Cowgill L, Davidson M, et al, and the American College of Veterinary Internal Medicine. Guidelines for the identification, evaluation, and management of systemic hypertension in dogs and cats. J Vet Intern Med 2007; 21(3): 542-558. http://dx.doi. org/10.1111/j.1939-1676.2007.tb03005.x. PMid:17552466

Churg J, Bernstein J, Glassock RJ. Renal disease: classification and atlas of glomerular disease. 2nd ed. New York: Igaku-shoin; 1995. 541 p.

Cortadellas O, del Palacio MJF, Bayón A, Albert A, Talavera J. Systemic hypertension in dogs with leishmaniasis: prevalence and clinical consequences. J Vet Intern Med 2006; 20(4): 941-947. http://dx.doi. org/10.1111/j.1939-1676.2006.tb01809.x. PMid:16955820

Costa FAL, Guerra JL, Silva SMMS, Klein RP, Mendonça IL, Goto H. CD4(+) T cells participate in the nephropathy of canine visceral leishmaniasis. Braz J Med Biol Res 2000; 33(12): 1455-1458. http:// dx.doi.org/10.1590/S0100-879X2000001200009. PMid:11105098

Costa FAL, Goto H, Saldanha LCB, Silva SMMS, Sinhorini IL, Silva TC, et al. Histopathologic patterns of nephropathy in naturally acquired canine visceral leishmaniasis. Vet Pathol 2003; 40(6): 677-684. http:// dx.doi.org/10.1354/vp.40-6-677. PMid:14608021

Costa FAL, Prianti MG, Silva TC, Silva SMMS, Guerra JL, Goto H. $\mathrm{T}$ cells, adhesion molecules and modulation of apoptosis in visceral leishmaniasis glomerulonephritis. BMC Infect Dis 2010; 10(1): 112. http://dx.doi.org/10.1186/1471-2334-10-112. PMid:20459816

Ferrari HF, Carreira VS, Moreira MAB, Da Matta VR, Haga CH, Luvizotto MCR. Morphological, immunohistochemical and molecular study of renal lesions in canine visceral leishmaniasis (CVL). Vet Zootec 2010; 17(1): 123-131.

Finco DR. Association of systemic hypertension with renal injury in dogs with induced renal failure. J Vet Intern Med 2004; 18(3): 289-294. http:// dx.doi.org/10.1111/j.1939-1676.2004.tb02547.x. PMid:15188813

International Renal Interesty Society - IRIS. IRIS staging of CKD [on line]. 2013 [cited 2014 Jan 29]. Available from: http://www.iris-kidney. com

Jacob F, Polzin DJ, Osborne CA, Neaton JD, Lekcharoensuk C, Allen TA, et al. Association between initial systolic blood pressure and risk of developing a uremic crisis or of dying in dogs with chronic renal failure. J Am Vet Med Assoc 2003; 222(3): 322-329. http://dx.doi.org/10.2460/ javma.2003.222.322. PMid:12564594

Jacob F, Polzin DJ, Osborne CA, Neaton JD, Kirk CA, Allen TA, et al. Evaluation of the association between initial proteinuria and morbidity rate or death in dogs with naturally occurring chronic renal failure. $J$
Am Vet Med Assoc 2005; 226(3): 393-400. http://dx.doi.org/10.2460/ javma.2005.226.393. PMid:15702689

Michell AR, Bodey AR, Gleadhill A. Absence of hypertension in dogs with renal insufficiency. Ren Fail 1997; 19(1): 61-68. http://dx.doi. org/10.3109/08860229709026260. PMid:9044452

Newman SJ, Confer AW, Panciera RJ. Sistema urinário. In: McGavin MD, Zachary JF. Bases da patologia em veterinária. Rio de Janeiro: Mosby Elsevier; 2009. p. 613-691.

Nieto CG, Navarrete I, Habela MA, Serrano F, Redondo E. Pathological changes in kidneys of dogs with natural Leishmania infection. Vet Parasitol 1992; 45(1-2): 33-47. http://dx.doi.org/10.1016/0304-4017(92)900255. PMid: 1485420

Planellas M, Roura X, Lloret A. Presence of renal disease in dogs with patent leishmaniasis. Parassitologia 2009; 51(1-2): 65-68.

Poli A, Abramo F, Mancianti F, Nigro M, Pieri S, Bionda A. Renal involvement in canine leishmaniasis. A light-microscopic, immunohistochemical and electron-microscopic study. Nephron 1991; 57(4): 444-452. http://dx.doi.org/10.1159/000186348. PMid:2046828

Polzin DJ. Chronic kidney disease. In: Ettinger SJ, Feldman EC. Veterinary internal medicine. 7th ed. Philadelphia: Saunders; 2012. p. 1990-2021.

Rigo RS, Carvalho CME, Honer MR, Andrade GB, Silva IS, Rigo $\mathrm{L}$, et al. Renal histopathological findings in dogs with visceral leishmaniasis. Rev Inst Med Trop Sao Paulo 2013; 55(2): 113-116. http:// dx.doi.org/10.1590/S0036-46652013000200008. PMid:23563764

Roura X, Fondati A, Lubas G, Gradoni L, Maroli M, Oliva G, et al. Prognosis and monitoring of leishmaniasis in dogs: a working group report. Vet J 2013; 198(1): 43-47. http://dx.doi.org/10.1016/j. tvjl.2013.04.001. PMid:23680263

SAS Institute Inc. The SAS System, release 9.2. Cary, North Carolina; 2008.

Schiffrin EL, Lipman ML, Mann JF. Chronic kidney disease: effects on the cardiovascular system. Circulation 2007; 116(1): 85-97. http://dx.doi. org/10.1161/CIRCULATIONAHA.106.678342. PMid:17606856

Serakides R. Sistema urinário. In: Santos RL, Alessi AC. Patologia veterinária. São Paulo: Roca; 2010. p. 291-336.

Shaw JJ. Further thoughts on the use of the name Leishmania (Leishmania) infantum chagasi for the aetiological agent of American visceral leishmaniasis. Mem Inst Oswaldo Cruz 2006; 101(5): 577-579. http:// dx.doi.org/10.1590/S0074-02762006000500017. PMid:17072466

Solano-Gallego L, Rodriguez-Cortes A, Trotta M, Zampieron C, Razia L, Furlanello T, et al. Detection of Leishmania infantum DNA by fret-based real-time PCR in urine from dogs with natural clinical leishmaniosis. Vet Parasitol 2007; 147(3-4): 315-319. PMid:17532143.

Solano-Gallego L, Miró G, Koutinas A, Cardoso L, Pennisi MG, Ferrer $\mathrm{L}$, et al. LeishVet guidelines for the practical management of canine leishmaniosis. Parasit Vectors 2011; 4: 86. PMid:21599936.

Tafuri WL, Michalick MSM, Dias M, Genaro O, Leite VHR, Barbosa AJA, et al. Estudo, ao microscópio óptico e eletrônico, do rim de cães natural e experimentalmente infectados com Leishmania (Leishmania) chagasi. Rev Inst Med Trop Sao Paulo 1989; 31(3): 139-145. http://dx.doi. org/10.1590/S0036-46651989000300002. PMid:2617010 
Wehner A, Hartmann K, Hirschberger J. Associations between proteinuria, systemic hypertension and glomerular filtration rate in dogs with renal and non-renal diseases. Vet Rec 2008; 162(5): 141-147. http:// dx.doi.org/10.1136/vr.162.5.141. PMid:18245745
Zatelli A, Borgarelli M, Santilli R, Bonfanti U, Nigrisoli E, Zanatta $\mathrm{R}$, et al. Glomerular lesions in dogs infected with Leishmania organisms. Am J Vet Res 2003; 64(5): 558-561. http://dx.doi.org/10.2460/ ajvr.2003.64.558. PMid:12755294 